\title{
Tolerance of upland rice cultivars to aluminum and acidic $\mathrm{pH}$
}

\author{
Lucas B. de Freitas ${ }^{1}$, Dirceu M. Fernandes ${ }^{1}$, Laércio A. Pivetta ${ }^{2} \&$ Suelen C. M. Maia $^{3}$ \\ ${ }^{1}$ Universidade Estadual Paulista/Faculdade de Ciências Agronômicas/Departamento de Solos e Recursos Ambientais. Botucatu, SP. E-mail: \\ lucasbarbosaf@yahoo.com.br (Corresponding author);dmfernandes@fca.unesp.br \\ ${ }^{2}$ Universidade Federal do Paraná/Setor Palotina/Departamento de Ciências Agronômicas. Palotina, PR. E-mail: laerciopivetta@ufpr.br \\ ${ }^{3}$ Instituto Federal Goiano/Campus Avançado Cristalina. Cristalina, GO. E-mail: suelen.maia@ifgoiano.edu.br
}

\section{Key words:}

Oryza sativa L.

aluminum susceptibility

aluminum resistance

\begin{abstract}
A B S T R A C T
Although the upland rice has been known by its moderate tolerance to aluminum, the presence of exchangeable aluminum in acidic soils may inhibit and compromise the adequate plant growth. However, there are few reports detailing modern cultivars used by Brazilian farmers with respect to their susceptibility to aluminum toxicity. This study aimed to characterize the cultivars currently used in the upland rice production with respect to their tolerance to aluminum and their growth under low $\mathrm{pH}$ conditions without aluminum. The treatments were arranged in a randomized block design, in a $2 \times 9$ factorial scheme: presence and absence of aluminum in the nutrient solution and nine upland rice cultivars (BRS Monarca, BRS Pepita, BRS Bonança, BRS Primavera, BRS Sertaneja, Maravilha, IAC 202, ANCambará and ANa7007), with four replicates. Based on the distribution of upland rice cultivars in quartiles, they were divided into two groups; aluminum-tolerant group: BRS Pepita, BRS Primavera and ANa7007; and aluminum-susceptible group: BRS Monarca, BRS Bonança, BRS Sertaneja, Maravilha, IAC 202 and ANCambará.
\end{abstract}

\section{Palavras-chave:}

Oryza sativa L.

alumínio susceptibilidade

resistência à alumínio

\section{Tolerância de cultivares de arroz de terras altas ao alumínio e $\mathrm{pH}$ ácido}

\section{R E S U M O}

Apesar de o arroz de terras altas ser reconhecido por sua moderada tolerância ao alumínio, a presença de alumínio trocável em solos ácidos pode inibir e comprometer o crescimento adequado das plantas; no entanto, poucos são os relatos descrevendo, de forma detalhada, os cultivares modernos utilizados pelos agricultores brasileiros quanto a sua susceptibilidade à toxicidade de alumínio. Objetivou-se neste estudo caracterizar os cultivares atualmente utilizados na produção de arroz de terras altas em relação à tolerância ao alumínio e ao seu crescimento sob cultivo em condição de baixo $\mathrm{pH}$ sem alumínio. Os tratamentos foram dispostos em um delineamento em blocos casualizados, em esquema fatorial $2 \times 9$ : presença e ausência de alumínio na solução nutritiva e nove cultivares de arroz de terras altas (BRS Monarca, BRS Pepita, BRS Bonança, BRS Primavera, BRS Sertaneja, Maravilha, IAC 202, ANCambará e ANa7007), com quatro repetições. Com a distribuição dos cultivares de arroz de terras altas em quartis foi possível diferenciar os cultivares em dois grupos. Grupo tolerante ao $\mathrm{Al}^{3+}$ : BRS Pepita, BRS Primavera e ANa7007; grupo suscetível ao $\mathrm{Al}^{3+}$ : BRS Monarca, BRS Bonança BRS Sertaneja, Maravilha, IAC 202 e ANCambará. 


\section{INTRODUCTION}

Upland rice is considered as a plant moderately tolerant to aluminum $\left(\mathrm{Al}^{3+}\right)$ (Fageria, 1998) but its growth may be inhibited or reduced in soils with high contents of $\mathrm{Al}^{3+}$ (Mendonça et al., 2003; Freitas et al., 2006).

The roots of plants under stress by $\mathrm{Al}^{3+}$ have their growth interrupted and become stunted, breakable, with a few fine ramifications, increased rigidity and thickness of the cell wall and suffer alterations in the membrane proteins (Meriga et al., 2010; Motoda et al., 2010; Sun et al., 2010; Garzon et al., 2011; Guo et al., 2012). Consequently, the roots become inefficient in the uptake of water and nutrients, especially in deeper soil layers (Mendonça et al., 2003; Sun et al., 2010).

Modern upland rice cultivars are less tolerant to $\mathrm{Al}^{3+}$ in comparison to the traditional ones (Justino et al., 2006) due to the process of genetic improvement, through which the cultivars have lost this characteristic. In this context, there are few reports thoroughly describing the modern cultivars used by Brazilian farmers with respect to their susceptibility to $\mathrm{Al}^{3+}$.

There are only descriptions of the susceptibility of upland rice lines to $\mathrm{Al}^{3+}$ (Guimarães et al., 2006) and studies restricted to a small number of cultivars, which evaluate one tolerant and one non-tolerant cultivar to $\mathrm{Al}^{3+}$ (Mendonça et al., 2003; Justino et al., 2006). Therefore, this study aimed to characterize the cultivars currently used in the production of upland rice with respect to their tolerance to $\mathrm{Al}^{3+}$ and growth cultivated under low $\mathrm{pH}$ condition without aluminum.

\section{Material ANd Methods}

Two experiments were carried out in a greenhouse at the Department of Soils and Environmental Resources of the Faculty of Agronomic Sciences, UNESP, Botucatu, SP.

\section{Experiment I: Upland rice tolerance to $\mathrm{Al}^{3+}$ toxicity in nutrient solution}

The experimental design was in randomized blocks, in a $2 \times 9$ factorial scheme, with four replicates. The treatments consisted of the presence and absence of $\mathrm{Al}^{3+}$ in the nutrient solution and nine upland rice cultivars (Embrapa - BRS Monarca, BRS Pepita, BRS Bonança, BRS Primavera, BRS Sertaneja and Maravilha; Agronomic Institute of Campinas (IAC) - IAC 202; Agronorte - ANCambará and ANa7007). The evaluated cultivars were selected among the most used ones in upland rice-producing regions. Embrapa, Agronorte and IAC were contacted and provided this information and the seeds.

The experiment used the nutrient solution described by the study of $\mathrm{Al}^{3+}$ tolerance of rice plants developed by Furlani \& Furlani (1988) and adapted by Zonta (2003), which was composed of $1.42 \mathrm{Ca}, 1.51 \mathrm{~K}, 0.33 \mathrm{Mg}, 0.95 \mathrm{~N}-\mathrm{NO}_{3}, 0.41$ $\mathrm{N}-\mathrm{NH}_{4}, 0.01 \mathrm{P}, 0.21 \mathrm{~S}, 0.21 \mathrm{Cl}, 0.22 \mathrm{Fe}, 0.009 \mathrm{Mn}, 0.008 \mathrm{~B}$, $0.00076 \mathrm{Zn}$ and $0.00031 \mathrm{Cu} \mathrm{mmol} \mathrm{L}^{-1}$. The concentration and source of $\mathrm{Al}^{3+}$ were $1.48 \mathrm{mmol} \mathrm{L}^{-1}$ and $\mathrm{AlCl}_{3} \cdot 6 \mathrm{H}_{2} \mathrm{O}$, respectively.

In order to obtain seedlings for the experiment, the rice seeds were treated with carboxin + thiram $(400 \mathrm{~mL}$ per 100 $\mathrm{kg}$ of seeds) and then placed to germinate in germinators with controlled light $(12 \mathrm{~h})$ and temperature $\left(25^{\circ} \mathrm{C}\right)$.
After the period of seed germination, the seedlings were selected with respect to uniformity in form and size and transferred to plastic pots containing $4 \mathrm{~L}$ of nutrient solution, at half ionic strength. Polystyrene lids were used to fix the plants in the pots (6 plants pot $\left.{ }^{-1}\right)$.

At 7 days after transplanting (DAT), the solution was substituted and nutrient solution without dilution was added, which remained under these conditions until 21 DAT. After this period, the treatments with $\mathrm{Al}^{3+}$ were applied and the plants were cultivated with the treatments until 42 DAT.

During the entire experimental period, the nutrient solution was aerated and the $\mathrm{pH}$ was daily monitored, maintained around $4.0( \pm 0.1)$ and corrected using $\mathrm{NaOH}$ $\left(0.1 \mathrm{~mol} \mathrm{~L}^{-1}\right)$ and $\mathrm{HCl}\left(0.1 \mathrm{~mol} \mathrm{~L}^{-1}\right)$. The nutrient solution was weekly renewed by adding the respective treatments and the losses through evapotranspiration were daily replenished with demineralized water. Heaters were used in the greenhouse in order to maintain the temperature at approximately $25^{\circ} \mathrm{C}$.

Plants were evaluated for root mean length and diameter (WinRhizo); root dry matter, shoot dry matter and the "S" index of susceptibility to $\mathrm{Al}^{3+}$, according to Fisher \& Maurer (1978) adapted by Guimarães et al. (2006) for $\mathrm{Al}^{3+}$ stress, as shown in Eqs. 1 and 2:

$$
\begin{aligned}
& \mathrm{IS}=\frac{\mathrm{Yi}-\mathrm{Ys}}{\mathrm{Yi} \times \mathrm{D}} \\
& \mathrm{D}=\frac{1-\mathrm{Yms}}{\mathrm{Ymi}}
\end{aligned}
$$

where:

D - severity of the applied stress;

Yi and Ys - root lengths without and with stress, respectively; and,

Yms and Ymi - mean root lengths of the experiment, with and without stress, respectively.

For the selection, the cultivars were distributed in quartiles, delimited by the mean root length, without the stress of $\mathrm{Al}^{3+}$ toxicity, plus $75 \%$ of its standard deviation and the mean of its $\mathrm{Al}^{3+}$ toxicity susceptibility index, minus $25 \%$ of its standard deviation. Thus, the lower the IS, the less affected the plants are by the stress level induced by $\mathrm{Al}^{3+}$ toxicity.

The data of the other variables were subjected to analysis of variance by $\mathrm{F}$ test and the means were compared by the Scott-Knott test, for cultivars, and F test for the comparison between the presence and absence of $\mathrm{Al}^{3+}$ treatments, both at 0.05 probability level.

\section{Experiment II: Upland rice cultivation in aluminic soil}

The experimental design was in randomized blocks, with four replicates, and the treatments were the same nine upland rice cultivars used in Experiment I. However, they were cultivated in pots containing aluminic soil $(\mathrm{m} \%>50 \%)$ and evaluated for the number of panicles per plant, grain production, shoot dry matter and harvest index of the cultivars under stress by $\mathrm{Al}^{3+}$. The harvest index was determined through the relationship of grain production/shoot dry matter production. 
The soil used in the experiment was of low natural fertility and aluminic, classified as Dark Red Latosol, with medium sandy texture, which showed the following chemical characteristics: $7 \mathrm{mg} \mathrm{dm}^{-3}$ of P-resin; $15 \mathrm{~g} \mathrm{dm}^{-3}$ of organic matter; $4.1 \mathrm{of} \mathrm{pH}$ in $\mathrm{CaCl}_{2} ; 0.7,5,3,69,11$ and $78 \mathrm{mmol}_{\mathrm{c}} \mathrm{dm}^{-3}$ of $\mathrm{K}, \mathrm{Ca}, \mathrm{Mg}, \mathrm{H}+$ $\mathrm{Al}, \mathrm{Al}^{3+}$ and $\mathrm{CEC}$, respectively; and $55.8 \%$ of saturation by $\mathrm{Al}^{3+}$.

The data were subjected to analysis of variance and the means were compared by the Scott-Knott test at 0.05 probability level.

\section{Results AND Discussion}

The cultivars were divided into two groups: the first one was composed of BRS Pepita, BRS Primavera and ANa7007, whose $\mathrm{Al}^{3+}$ susceptibility index of the root growth was lower than 0.93 , being considered as tolerant to $\mathrm{Al}^{3+}$, while the second group was composed of the cultivars BRS Monarca, BRS Bonança, BRS Sertaneja, Maravilha, IAC 202 and ANCambará, which obtained $\mathrm{Al}^{3+}$ susceptibility index higher than 0.93 , thus being considered as susceptible to $\mathrm{Al}^{3+}$ (Figure 1).

The cultivars BRS Monarca, BRS Bonança and ANCambará stand out for their higher root growth when grown in the absence of $\mathrm{Al}^{3+}$, i.e., only under the condition of high acidity ( $\mathrm{pH}$ 4.0). It is worth remembering that the lower the $\mathrm{Al}^{3+}$ susceptibility index, the less affected the cultivar is by the deleterious effects of the $\mathrm{Al}^{3+}$.

It is interesting to note that the division by quartiles separated only three cultivars as tolerant to $\mathrm{Al}^{3+}$, according to the adopted criteria. Thus, although upland rice is considered as a plant moderately tolerant to $\mathrm{Al}^{3+}$ (Fageria, 1998), its growth can be influenced by $\mathrm{Al}^{3+}$, confirming the results reported by Ferreira et al. (1995), Mendonça et al. (2003) and Freitas et al. (2006).

The distribution of the cultivars in quartiles (root growth) was used to separate them with respect to the tolerance to $\mathrm{Al}^{3+}$; however, from this point on, the cultivars will be evaluated considering their efficiency under stress by $\mathrm{Al}^{3+}$, as well as in

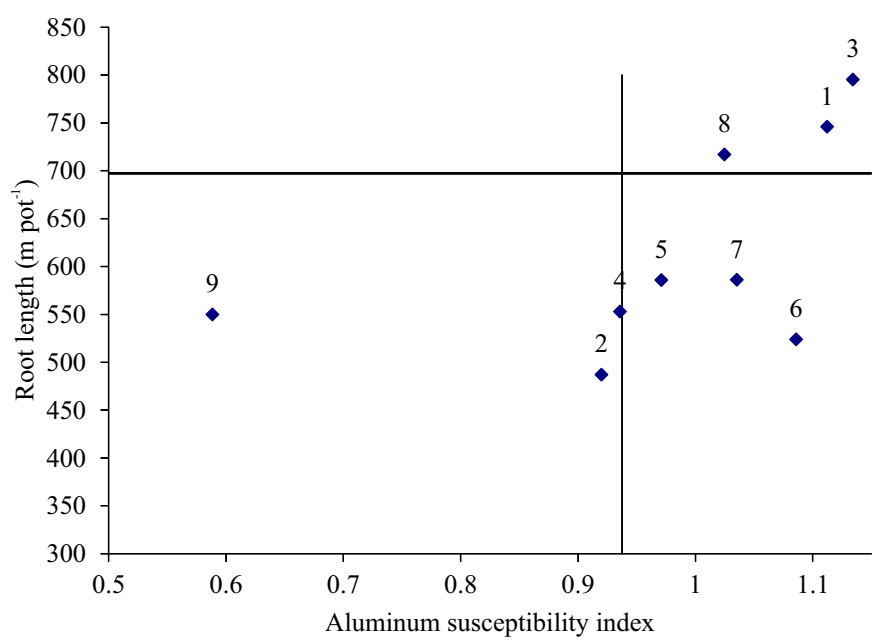

1 - BRS Monarca, 2 - BRS Pepita, 3 - BRS Bonança, 4 - BRS Primavera, 5 - BRS Sertaneja, 6 - Maravilha; 7 - IAC 202; 8 - ANCambará and 9 - ANa7007

Figure 1. Distribution of the cultivars in quartiles delimited by the root length in $0 \mathrm{mg} \mathrm{dm}^{-3}$ of aluminum and by the susceptibility index of root growth to aluminum toxicity, at the points determined by the mean root length (without $\left.\mathrm{Al}^{3+}\right)+75 \%$ of its standard deviation and by the mean root susceptibility index to aluminum - $25 \%$ of its standard deviation cultivation in the absence of $\mathrm{Al}^{3+}$, since they were cultivated at $\mathrm{pH} 4.0$, which is close to the $\mathrm{pH}$ at which the upland rice crop is cultivated especially in recently deforested areas.

The cultivar BRS Monarca showed higher shoot and root dry matter production when cultivated in the presence and absence of $\mathrm{Al}^{3+}$ (Table 1). On the other hand, comparing the cultivation in the presence and absence of $\mathrm{Al}^{3+}$, the shoot dry matter production of the cultivars BRS Monarca, Maravilha and $\mathrm{ANa} 7007$ were lower in the presence of $\mathrm{Al}^{3+}$.

The cultivars BRS Pepita and ANa7007 were classified as tolerant to $\mathrm{Al}^{3+}$ according to the method of separation by quartiles (Figure 1); hence, it can be noted that, in comparison to the other cultivars, these two produce lower amount of shoot dry matter. Thus, it is possible that this variable is little influenced by $\mathrm{Al}^{3+}$ toxicity caused to the roots. Therefore, this variable is probably not indicated for the classification of cultivars regarding their tolerance to $\mathrm{Al}^{3+}$.

The cultivars BRS Pepita, Maravilha and ANa7007 obtained lower root dry matter production when cultivated in the presence and absence of $\mathrm{Al}^{3+}$; however, among the cultivars, only BRS Pepita was not different in the comparison of cultivation in the presence and absence of $\mathrm{Al}^{3+}$.

It is known that root dry matter production is negatively influenced by the action of $\mathrm{Al}^{3+}$ (Roy \& Bhadra, 2014). Despite the lower root dry matter production in the presence of $\mathrm{Al}^{3+}$ (Table 1), the cultivars BRS Pepita and ANa7007 were considered as tolerant through the separation in quartiles (Figure 1). Thus, the methodology of separation into quartiles is important to distinguish the cultivars and it is basically a relationship between root length in the presence and in the absence of $\mathrm{Al}^{3+}$. Therefore, both cultivars showed lower difference between the root growth in the presence and absence of $\mathrm{Al}^{3+}$ in comparison to the others.

It is also necessary to consider that, before root dry matter shows a decrease caused by $\mathrm{Al}^{3+}$ toxicity, this phytotoxic element acts first in root elongation and, consequently, leads to lower root length (Sun et al., 2010; Roy \& Bhadra, 2014).

The cultivars BRS Monarca, BRS Bonança and ANCambará showed greater root length when grown in the absence of $\mathrm{Al}^{3+}$ in comparison to the others (Table 2). This behavior can contribute to explaining the classification of the cultivar BRS Monarca as susceptible to $\mathrm{Al}^{3+}$ (Figure 1), since there was great amplitude between the root growth in the absence and presence of $\mathrm{Al}^{3+}$, evidencing the damaging action of $\mathrm{Al}^{3+}$.

Table 1. Shoot and root dry matter production of upland rice cultivars grown in the presence $\left(+\mathrm{Al}^{3+}\right)$ and absence $\left(-\mathrm{Al}^{3+}\right)$ of aluminum

\begin{tabular}{|c|c|c|c|c|}
\hline \multirow[t]{2}{*}{ Cultivars } & \multicolumn{2}{|c|}{$\begin{array}{l}\text { Shoot dry matter } \\
\left(\mathrm{g} \mathrm{pot}^{-1}\right)\end{array}$} & \multicolumn{2}{|c|}{$\begin{array}{l}\text { Root dry matter } \\
\left(\mathrm{g} \mathrm{pot}^{-1}\right)\end{array}$} \\
\hline & $-\left.A\right|^{3+}$ & $+\mathrm{Al}^{3+}$ & $-\mathrm{Al}^{3+}$ & $+\mathrm{Al}^{3+}$ \\
\hline BRS Monarca & $8.1 \mathrm{aA}$ & $7.1 \mathrm{aB}$ & $2.3 \mathrm{aA}$ & $2.1 \mathrm{aA}$ \\
\hline BRS Pepita & $4.1 \mathrm{cA}$ & $3.8 \mathrm{bA}$ & $1.2 \mathrm{cA}$ & $1.0 \mathrm{cA}$ \\
\hline BRS Bonança & $6.5 \mathrm{bA}$ & $6.0 \mathrm{aA}$ & $2.0 \mathrm{bA}$ & $1.7 \mathrm{bB}$ \\
\hline BRS Primavera & $6.7 \mathrm{bA}$ & $6.2 \mathrm{aA}$ & $1.9 \mathrm{bA}$ & $1.6 \mathrm{bB}$ \\
\hline BRS Sertaneja & $6.6 \mathrm{bA}$ & $5.9 \mathrm{aA}$ & $1.9 \mathrm{bA}$ & $1.4 \mathrm{bB}$ \\
\hline Maravilha & $5.0 \mathrm{cA}$ & $4.1 \mathrm{bB}$ & $1.5 \mathrm{cA}$ & $1.0 \mathrm{cB}$ \\
\hline IAC 202 & $6.3 \mathrm{bA}$ & $6.1 \mathrm{aA}$ & $1.7 \mathrm{bA}$ & $1.7 \mathrm{bA}$ \\
\hline ANCambará & $6.4 \mathrm{bA}$ & $5.8 \mathrm{aA}$ & $1.9 \mathrm{bA}$ & $1.6 \mathrm{bB}$ \\
\hline ANa7007 & $4.6 \mathrm{cA}$ & $3.5 \mathrm{bB}$ & $1.2 \mathrm{cA}$ & $0.6 \mathrm{~dB}$ \\
\hline CV (\%) & \multicolumn{2}{|c|}{9.0} & \multicolumn{2}{|c|}{9.7} \\
\hline
\end{tabular}

Means followed by different letters, uppercase in rows and lowercase in columns, differ statistically at 0.05 probability level by Scott-Knott tests, respectively 
Table 2. Root length and diameter of upland rice cultivars grown in the presence $\left(+\mathrm{Al}^{3+}\right)$ and absence $\left(-\mathrm{Al}^{3+}\right)$ of aluminum

\begin{tabular}{lccccc}
\hline \multirow{2}{*}{ Cultivars } & \multicolumn{2}{c}{ Root length $\left(\mathbf{m ~ p o t}^{-1}\right)$} & & \multicolumn{2}{c}{ Mean diameter $(\mathbf{m m})$} \\
\cline { 2 - 3 } \cline { 5 - 7 } & $-\mathrm{Al}^{3+}$ & $+\mathrm{Al}^{3+}$ & & $-\mathrm{Al}^{3+}$ & $+\mathrm{Al}^{3+}$ \\
BRS Monarca & $745.8 \mathrm{aA}$ & $227.9 \mathrm{bB}$ & & $0.199 \mathrm{aA}$ & $0.306 \mathrm{aB}$ \\
BRS Pepita & $487.0 \mathrm{bA}$ & $206.6 \mathrm{bB}$ & & $0.178 \mathrm{bA}$ & $0.248 \mathrm{cB}$ \\
BRS Bonança & $795.2 \mathrm{aA}$ & $233.2 \mathrm{bB}$ & & $0.175 \mathrm{bA}$ & $0.252 \mathrm{cB}$ \\
BRS Primavera & $552.7 \mathrm{bA}$ & $229.6 \mathrm{bB}$ & & $0.204 \mathrm{aA}$ & $0.255 \mathrm{cB}$ \\
BRS Sertaneja & $585.9 \mathrm{bA}$ & $229.0 \mathrm{bB}$ & & $0.207 \mathrm{aA}$ & $0.264 \mathrm{cB}$ \\
Maravilha & $524.0 \mathrm{bA}$ & $168.4 \mathrm{bB}$ & & $0.198 \mathrm{aA}$ & $0.278 \mathrm{bB}$ \\
IAC 202 & $586.0 \mathrm{bA}$ & $208.5 \mathrm{bB}$ & & $0.208 \mathrm{aA}$ & $0.300 \mathrm{aB}$ \\
ANCambará & $716.7 \mathrm{aA}$ & $254.2 \mathrm{bB}$ & & $0.178 \mathrm{bA}$ & $0.247 \mathrm{cB}$ \\
ANa7007 & $549.8 \mathrm{bA}$ & $331.8 \mathrm{aB}$ & & $0.177 \mathrm{bA}$ & $0.165 \mathrm{dA}$ \\
CV (\%) & \multicolumn{2}{c}{12.4} & & \multicolumn{2}{c}{6.6} \\
\hline
\end{tabular}

Means followed by different letters, uppercase in rows and lowercase in columns, diffe statistically at 0.05 probability level by Scott-Knott tests, respectively

On the other hand, it is observed that the cultivar ANa7007 in the presence of $\mathrm{Al}^{3+}$, despite showing lower shoot and root dry matter production (Table 1), has the greatest root length among all cultivars when grown under stress by $\mathrm{Al}^{3+}$ (Table 2), confirming its selection as tolerant to $\mathrm{Al}^{3+}$ (Figure 1).

The cultivar ANa7007 showed the lowest root diameter in both types of cultivation (absence and presence of $\mathrm{Al}^{3+}$ ) (Table 2); this behavior can contribute to explaining the low root dry matter production of this cultivar (Table 1).

The root diameter referring to the cultivation in the absence of $\mathrm{Al}^{3+}$ can be considered as a reference for comparison (Table 2 ) due to the increment in root diameter caused by $\mathrm{Al}^{3+}$ toxicity (Motoda et al., 2010). Hence, comparing the cultivars in the presence and absence of $\mathrm{Al}^{3+}$, the effect of root thickening favored by the toxicity occurred for almost all the cultivars, except for ANa7007.

The cultivar BRS Monarca stands out for the increment of $0.107 \mathrm{~mm}$ in mean root diameter, in the comparison of cultivated in the presence and absence of $\mathrm{Al}^{3+}$, and it was the highest value observed among the nine tested cultivars (Table 2 ). Therefore, this variable can also support the selection of this cultivar as susceptible to $\mathrm{Al}^{3+}$.

Given the presented results and in general, the cultivars BRS Monarca, BRS Bonança, BRS Primavera, BRS Sertaneja, IAC 202 and ANCambará obtained adequate growth without the presence of $\mathrm{Al}^{3+}$ and at acidic $\mathrm{pH}$ (4.0); thus, these cultivars are interesting for cultivation in soils with acidic $\mathrm{pH}$, but without high content of $\mathrm{Al}^{3+}$, while the cultivars BRS Pepita and Maravilha obtained lower growth when cultivated in the presence of $\mathrm{Al}^{3+}$.

Even in the presence of $\mathrm{Al}^{3+}$, the cultivar BRS Monarca showed good dry matter production (Table 1); in spite of that, it showed small root growth when cultivated under these conditions (Table 2), being strongly affected by this phytotoxic ion. In contrast, the cultivar ANa7007 stood out as tolerant to $\mathrm{Al}^{3+}$ (Figure 1) due to the high root growth obtained under stress by $\mathrm{Al}^{3+}$ (Table 2); however, it showed the lowest shoot and root dry matter production among the evaluated cultivars (Table 1). Therefore, it is suggested to study methodologies for the selection of cultivars tolerant and susceptible to $\mathrm{Al}^{3+}$ in order to increase the efficiency of the test and obtain greater understanding about the reflex of the variables root dry matter and root length on grain production, since not always a plant is able to produce large amount of root dry matter or the shoots are able to convert this produced dry matter into grains; ultimately, this is the objective of the rural producer.

To reinforce the results of the Experiment I (nutrient solution), a second experiment was conducted with the same cultivars; however, they were grown in pots with aluminic soil (Table 3).

The cultivars BRS Primavera and ANa7007 showed higher grain production and also low shoot dry matter production, demonstrating good harvest index. These results reinforce the definition of the cultivars BRS Primavera and ANa7007 as tolerant to $\mathrm{Al}^{3+}$ (Figure 1), which showed interesting agronomic characteristics for high yield (Table 3).

As to the cultivars BRS Sertaneja and Maravilha, selected as susceptible to $\mathrm{Al}^{3+}$ based on the experiment in nutrient solution (Figure 1), despite obtaining the highest shoot dry matter production among the tested cultivars (Table 3 ), they showed low grain production and, consequently, the worst harvest index among the cultivars. Therefore, their definition as susceptible to $\mathrm{Al}^{3+}$ is reinforced. These results were similar to those reported by Mendonça et al. (2003) and Justino et al. (2006), who also observed the susceptibility of the cultivar Maravilha to $\mathrm{Al}^{3+}$.

These results demonstrate that shoot dry matter production may not be efficient in the selection of the cultivars, because the cultivar BRS Sertaneja showed higher shoot dry matter production, but its grain production was lower compared with the cultivars that produced less shoot dry matter (Table 3).

Lastly, studies like these are initially important since they are basic experiments, i.e., it is the first study to be conducted aiming to obtain possible characteristics of tolerance to $\mathrm{Al}^{3+}$ in cultivars. However, it is important to evaluate the studied cultivars in field experiments and in different regions, because it is the only way to permanently differentiate the cultivars with respect to their tolerance to $\mathrm{Al}^{3+}$.

Table 3. Number of panicles plant ${ }^{-1}$, grain production, shoot dry matter and harvest index of upland rice cultivars grown in aluminic soil

\begin{tabular}{lcccc}
\hline \multicolumn{1}{c}{ Cultivars } & $\begin{array}{c}\text { Panicles } \\
\text { plant }^{-1}\end{array}$ & $\begin{array}{c}\text { Grain } \\
\text { production }\end{array}$ & $\begin{array}{c}\text { Shoot } \\
\text { dry matter }\end{array}$ & $\begin{array}{c}\text { Harvest } \\
\text { index }\end{array}$ \\
\cline { 2 - 5 } BRS Monarca & \multicolumn{4}{c}{ (g pot $^{-1}$ ) } \\
BRS Pepita & $18.5 \mathrm{C}$ & $50.0 \mathrm{~b}$ & $48.0 \mathrm{C}$ & $1.0 \mathrm{C}$ \\
BRS Bonança & $14.7 \mathrm{C}$ & $42.0 \mathrm{~b}$ & $45.7 \mathrm{C}$ & $1.0 \mathrm{C}$ \\
BRS Primavera & $15.2 \mathrm{C}$ & $62.0 \mathrm{a}$ & $46.2 \mathrm{C}$ & $0.9 \mathrm{~d}$ \\
BRS Sertaneja & $18.7 \mathrm{~b}$ & $48.5 \mathrm{~b}$ & $58.0 \mathrm{~b}$ & $1.2 \mathrm{~b}$ \\
Maravilha & $15.5 \mathrm{C}$ & $47.0 \mathrm{C}$ & $60.2 \mathrm{a}$ & $0.8 \mathrm{~d}$ \\
IAC 202 & $16.2 \mathrm{C}$ & $53.2 \mathrm{~b}$ & $51.2 \mathrm{~b}$ & $1.0 \mathrm{C}$ \\
ANCambará & $14.5 \mathrm{C}$ & $46.7 \mathrm{C}$ & $53.2 \mathrm{~b}$ & $0.8 \mathrm{~d}$ \\
ANa7007 & $32.0 \mathrm{a}$ & $59.5 \mathrm{a}$ & $39.2 \mathrm{~d}$ & $1.5 \mathrm{a}$ \\
CV (\%) & 8.2 & 5.6 & 8.5 & 13.9 \\
\hline
\end{tabular}

Means followed by different letters for each parameter differ by the Scott-Knott test at 0.05 probability level

\section{Conclusions}

1. With the distribution of the upland rice cultivars in quartiles, it was possible to differentiate them in two groups. $\mathrm{Al}^{3+}$ tolerant group: BRS Pepita, BRS Primavera and ANa7007; $\mathrm{Al}^{3+}$ susceptible group: BRS Monarca, BRS Bonança BRS Sertaneja, Maravilha, IAC 202 and ANCambará. 
2. The cultivars BRS Primavera and ANa7007 show higher grain production when cultivated in aluminic soil.

3. The cultivars BRS Monarca, BRS Bonança, BRS Primavera, BRS Sertaneja, IAC 202 and ANCambará have adequate growth when cultivated in nutrient solution with acidic $\mathrm{pH}(4.0)$ and in the absence of $\mathrm{Al}^{3+}$.

\section{Acknowledgments}

To the São Paulo Research Foundation (FAPESP), for the financial support granted through the doctorate scholarship to the first author (grant \#2011/09283-0) and the project of regular support to the research (grant \# 2011/22182-8).

To the National Council for Scientific and Technological Development $(\mathrm{CNPq})$ for providing a research grant to the second author.

To the Brazilian Agricultural Research Corporation (EMBRAPA), AGRONORTE and the APTA Regional/SAASP - Centro Oeste, for providing the seeds of the evaluated upland rice cultivars.

\section{Literature Cited}

Fageria, N. K. Otimização da eficiência nutricional na produção das culturas. Revista Brasileira de Engenharia Agrícola e Ambiental, v.2, p.6-16, 1998. http://dx.doi.org/10.1590/1807-1929/agriambi. v02n01p6-16

Ferreira, R. P.; Cruz, C. D.; Sediyama, C. S.; Fageria, N. K. Identificação de cultivares de arroz tolerantes à toxidez de alumínio por técnica multivariada. Pesquisa Agropecuária Brasileira, v.30, p.789-795, 1995.

Fisher, R. A.; Maurer, R. Drought resistance in spring wheat cultivars. I. Grain yield responses. Australian Journal of Agricultural Research, v.29, p.897-912, 1978. http://dx.doi.org/10.1071/AR9780897

Freitas, F. A.; Kopp, M. M.; Sousa, R. O.; Zimmer, P. D.; Carvalho, F. I. F.; Oliveira, A. C. Absorção de P, Mg, Ca e K e tolerância de genótipos de arroz submetidos a estresse por alumínio em sistemas hidropônicos. Ciência Rural, v.36, p.72-79, 2006. http:// dx.doi.org/10.1590/S0103-84782006000100011

Furlani, P. R.; Furlani, A. M. Composição de pH de solução nutritiva para estudos fisiológicos e seleção de plantas em condições nutricionais adversas. Campinas: Instituto Agronômico, 1988. 34p. Boletim Técnico, 121
Garzon, T.; Gunse, B.; Moreno, A. R.; Tomos, A. D.; Barcelo, J.; Poschenrieder, C. Aluminium-induced alteration of ion homeostasis in root tip vacuoles of two maize varieties differing in Al tolerance. Plant Science, v.180, p.709-715, 2011. http://dx.doi. org/10.1016/j.plantsci.2011.01.022

Guimarães, C. M.; Neves, P. C. F.; Stone, L. F.; Zimmermann, F. J. P. Resistência do arroz de terras altas ao alumínio. Revista Brasileira de Engenharia Agrícola e Ambiental, v.10, p.855-860, 2006. http:// dx.doi.org/10.1590/S1415-43662006000400011

Guo, T. R.; Yao, P. C.; Zhang, Z. D.; Wang, J. J.; Wang, M. Involvement of antioxidative defense system in rice growing seedlings exposed to aluminum toxicity and phosphorus deficiency. Rice Science, v.19, p.207-2012, 2012. http://dx.doi.org/10.1016/S16726308(12)60042-0

Justino, G. C.; Cambraia, J.; Oliva, M. A.; Oliveira, J. A. Absorção e redução de nitrato em duas cultivares de arroz na presença de alumínio. Pesquisa Agropecuária Brasileira, v.41, p.1285-1290, 2006. http://dx.doi.org/10.1590/S0100-204X2006000800011

Mendonça, R. J.; Cambraia, J.; Oliveira, J. A.; Oliva, M. A. Efeito do alumínio na absorção e na utilização de macronutrientes em duas cultivares de arroz. Pesquisa Agropecuária Brasileira, v.38, p.843846, 2003. http://dx.doi.org/10.1590/S0100-204X2003000700008 Meriga, B.; Attitalla, I. H.; Ramgopal, M.; Ediga, A.; Kavikishor, P. B. Differential tolerance to aluminum toxicity in rice cultivars: Involvement of antioxidative enzymes and possible role of aluminum resistant locus. Academic Journal of Plant Sciences, v.3, p.53-63, 2010.

Motoda, H.; Kano, Y.; Hiragami, F.; Kawamura, K.; Matsumoto, H. Morphological changes in the apex of pea roots during and after recovery from aluminum treatment. Plant Soil, v.333, p.49-58, 2010. http://dx.doi.org/10.1007/s11104-010-0318-1

Roy, B.; Bhadra, S. Effects of toxic levels of aluminium on seedling parameters of rice under hydroponic culture. Rice Science, v.21, p.217-223, 2014. http://dx.doi.org/10.1016/S1672-6308(13)60182-1

Sun, P.; Tian, Q. Y.; Chen, J.; Zhang, W. H. Aluminum-induced inhibition of root elongation in Arabidopsis is mediated by Ethylene and Auxin. Journal of Experimental Botany, v.61, p.346356, 2010. http://dx.doi.org/10.1093/jxb/erp306

Zonta, E. Estudos da tolerância ao alumínio em arroz de sequeiro e seus efeitos sobre a interface solo-planta. Rio de Janeiro: UFRJ, 2003. 139p. Tese Pós-Doutorado 